\author{
Dorota Siwor \\ Uniwersytet Jagielloński \\ dorota.siwor@uj.edu.pl
}

\title{
„Wszystko jest powtórzone na jednym ostrzu noża"1. O doświadczeniu utraty w Przebudzeniach Tadeusza Nowaka
}

\author{
"Everything is Repeated on a Single Blade of Knife." About the Experience \\ of Loss in Tadeusz Nowak's Przebudzenia
}

\begin{abstract}
The article is devoted to the prose debut of Tadeusz Nowak; however, the volume Przebudzenia [Awakenings] is interpreted in the context of his later writings. The suggestions concerning the interpretation of the title word point at some notions crucial for understanding Nowak's prose writing: the feeling of yearning for what has been lost and suffering incurred by the awareness of lack. The shape of a circle plays a significant role in these deliberations, since repetition seems to be the antidote for fading away and dying. Writing - here also understood as a form of repetition - becomes a necessary and continually undertaken attempt to heal the wound caused by the experience of loss.
\end{abstract}

Keywords: Tadeusz Nowak, Przebudzenia, loss, metaphor of a circle, longing

Streszczenie: Artykuł poświęcony jest debiutowi prozatorskiemu Tadeusza Nowaka, jednak Przebudzenia interpretowane są w kontekście późniejszej jego twórczości. Propozycje odczytywania tytułowego słowa zmierzają do wskazania kluczowych dla rozumienia prozy Nowaka zagadnień: tęsknoty za utraconym, cierpienia wynikającego ze świadomości braku. Istotną rolę w tych rozważaniach odgrywa figura koła, powtarzanie bowiem wydaje się antidotum przeciw zanikaniu i śmierci. Pisanie - rozumiane także jako forma powtórzenia staje się konieczną i stale podejmowaną próbą zasklepiania rany wywołanej przez doświadczenie utraty.

Słowa kluczowe: Tadeusz Nowak, Przebudzenia, strata, metafora koła, tęsknota

Moje czytanie prozy Nowaka to nieustające zataczanie kręgów. Od ostatniej powieści do debiutanckich Przebudzeń, od jednych motywów ku innym,

${ }^{1}$ T. Nowak, Wszystko jest powtórzone [w:] tegoż, Jasetkowe niebiosa, Warszawa 1957, s. 42. 
przez ich ciągłe powtórzenia, powroty. Owo nawracanie jest także immanentnie wpisane w samo dzieło autora Diabtów, a ponowienia można odczytywać w różnych kontekstach. Metafora koła, kręgu, ich symbolika są jednymi z kluczowych elementów tej twórczości. Jeden z tomików wierszy Nowaka nosi tytuł Ślepe kota wyobraźni, a koło i krąg są częstym motywem zarówno wierszy, jak i prozy. W dziele Nowaka idea powrotu, zamykania w krą, pozostawania w nim lub przekraczania wyraźnie dominuje. Wiąże się również zapewne z symboliką koła właściwą opowieści mitycznej, mit i baśń - w połączeniu z kulturą ludową - są bowiem dla autora Wniebogtosów nieustającym źródłem znaczeń. Tak też postrzegane jest ludzkie życie: jako zataczanie koła od narodzin do śmierci, dzieci i starcy są w tej koncepcji świata naturalnie sobie bliscy. Koło wyznacza także przestrzeń obejmującą świat Nowakowych utworów - wieś zazwyczaj ukazywana jest właśnie jako zamknięta w kręgu. Źródła takiego postrzegania miejsca tkwić mogą w doświadczeniu samego autora, jego rodzinna wieś była bowiem - jak określił to Stanisław Balbus „zamkniętą wyspą” z trzech stron oblaną wodami rzek, odgrodzoną od świa$\mathrm{ta}^{2}$. Koło jest w twórczości Nowaka nośnikiem wielu istotnych sensów, przede wszystkim wyznacza jednak porządek jej czytania: nie linearny, a oparty na powtórzeniu, powrotach.

Wielokrotnie odbywane wędrówki czytelnicze uświadamiają znaczenie pierwszego napisanego prozą utworu. W Przebudzeniach ${ }^{3}$ bowiem zawarł Tadeusz Nowak wiele motywów i kluczowych symboli, znaczeń, które pojawiają się w późniejszych prozach i ostatecznie budują całościowy sens jego dzieła ${ }^{4}$. Tymczasem dziś utwór został zupełnie niemal zapomniany.

Przebudzenia, choć często określane mianem opowiadań, są konsekwentnie budowaną całością, której nie można sprowadzić do zestawu odrębnych i samodzielnych tekstów. Kolejne całostki zajmują logicznie i artystycznie uzasadnione miejsce, wspólny jest narrator-bohater, choć czasem mogłoby się zdawać, że przemawiają przezeń inne postacie. Pod względem gatunkowym

${ }^{2}$ Film „Podróż do miejsca urodzenia”, scenariusz i reżyseria A. Czarnecka i D. Pawelec, TVP S.A. oddział w Krakowie dla Pr. 2, 2001.

Artystycznie przetworzony wizerunek Nowakowej wsi przedstawia grafika autorstwa Józefa Wilkonia, wykorzystana na okładce wydanych w 2015 roku szkiców i rozmów poety w zbiorze opracowanym przez Anitę Jarzynę, zatytułowanym Spowiedź wyobraźni (Wilkoń ilustrował też pierwsze wydanie Obcoplemiennej ballady). Grafika ukazuje wiejski pejzaż, gdzie całościowo uporządkowana przestrzeń (łąka ze zwierzętami, chaty, niebo) ujęta została w koliste obramowanie rzeki.

3 T. Nowak, Przebudzenia, Kraków 1962. Wszystkie cytaty pochodzą z tego wydania, w nawiasie podaję numer strony.

${ }^{4}$ Roch Sulima zauważył: „Przebudzenia można uznać za komentarz do poezji Nowaka oraz klucz do jej wyjaśniania i opisu. Zawierają one ponadto prawie wszystkie problematy i rozwiązania artystyczne istotne dla przyszłych tomów prozy pisarza" (R. Sulima, Tadeusz Nowak, Warszawa 1986, s. 82). Jednak książka Sulimy, ważna i wnikliwa, ukazała się w 1986 roku, gdy zainteresowanie pisarzem zdecydowanie już słabło. 
przypominają Przebudzenia na przykład Sklepy cynamonowe Brunona Schul$\mathrm{za}^{5}$, ale i wiele później powstałych utworów prozatorskich, których nie można jednoznacznie gatunkowo przyporządkować. Cechuje je także pewna rodzajowa niejednorodność, bliższe są może poematom pisanym prozą czy prozie poetyckiej ${ }^{6}$. Te nieprecyzyjne określenia tylko naskórkowo dotykają sedna cechą zarówno tego utworu Nowaka, jak i wielu fragmentów jego późniejszych powieści, jest szczególne nasycenie środkami wyrazu charakterystycznymi dla poezji. Silne są również związki tematyczne między poezją i prozą tego autora. Twórczość Nowaka stanowi wyrazistą i konsekwentnie budowaną całość, choć nie oznacza to braku wewnętrznych przemian. Czemu tak mocno podkreślam spójność jego dzieła? Otóż wydaje mi się, że wynika ona ze stałego nawracania do pewnych myśli, dylematów, doznań, których poeta - raz uznawszy za najbardziej istotne - nigdy nie porzucit, ale nigdy też jednoznacznie nie rozstrzygnął, nie uporał się z nimi, tak by uznać te kwestie za zamknięte. Stąd konieczność ponawiania, ubierania wciąż w nowe narracje, fabuły czy poetyckie monologi. Stąd ponownie figura koła jako jeden z istotnych kluczy otwierających Nowakowe dzieło.

Tytuł utworu spaja ten zbiór dodatkowo, choć jest także tytułem jednej z cząstek. Każda z całostek jest takim „przebudzeniem” - doświadczeniem jednostkowym, ale składającym się na pewną całość. Warto tu zwrócić uwagę na użycie liczby mnogiej, co podkreśla - znów - powtarzanie, wielokrotność owego aktu. Najbardziej oczywisty sens tytułu, to budzenie się świadomości, dorastanie do samodzielnego postrzegania świata. 'Przebudzić się' to przejrzeć, poznać, zrozumieć, zatem sens tych doznań wyraźnie wskazuje na dorastanie, dojrzewanie do wiedzy o sobie i świecie ${ }^{7}$. Potwierdza to biografia bohatera, której podporządkowana jest kompozycja tomu. W pierwszym tekście ukazane zostają myśli kilkuletniego dziecka, jego powolne rozglądanie się w otaczającej rzeczywistości, stopniowe odróżnianie snu od jawy. Wprost podkreślana jest niejasna jeszcze, dopiero rodząca się tożsamość chłopca, na przykład w słowach: „z moim nieustalonym jeszcze dla ludzi życiem przeniosłem się do stajni” (s. 18). Kolejne opowieści-rozdziały ukazują stopniowe zyskiwanie samoświadomości, budowanie własnego obrazu siebie, co najwyraźniej uwidacznia się w trzech Balladach: złodziejaszka, pomylonego i Chrystusika. Obok typowych adolescencyjnych atrybutów, jak popisy sprawności

${ }^{5}$ Podobieństw dałoby się tu wskazać więcej, ale nie jest to tematem tego szkicu.

${ }^{6}$ Por. na przykład uwagi Włodzimierza Boleckiego dotyczące poetyki prozy Schulza, w szczególności charakteru opisu [w:] tegoż, Poetycki model prozy $w$ dwudziestoleciu międzywojennym. Witkacy - Gombrowicz - Schulz, Kraków 1996, s. 225-315.

7 Ten inicjacyjny sens drogi chłopca tylko tu sygnalizuję, w innym miejscu pisałam o tym bowiem bardziej szczegółowo. Por. D. Siwor, W kreggu mitu, magii i rytuatu. O prozie Tadeusza Nowaka, Kraków 2002. Dogłębna analiza sensów zawartych w drodze ku świadomości siebie oraz znaczenia owej dorosłości ukazanej w Przebudzeniach byłaby bardzo interesująca, odbiega jednak nieco od celu tego szkicu. 
w gronie rówieśników czy pierwsze erotyczne fascynacje, pojawiają się i inne motywy charakterystyczne dla doświadczenia inicjacyjnego, takie jak udział w tajemnicach dorosłych (Staw), zetknięcie ze śmiercią, najpierw naturalną, później z grozą zabijania (Polowanie na anioła, Zabawy, Mojżesz). Wówczas też w świat chłopca zdecydowanie wkracza Historia (wojna, mordowanie Żydów), dotąd znajdująca się niejako poza jego horyzontem widzenia. Tytułowe Przebudzenia - przedostatni tekst - to opowieść o najważniejszym doświadczeniu oddzielenia od rodzinnego domu i wsi, o wyjeździe do miasteczka „na naukę”. Znamienne jest, że wówczas ugruntowuje się doznanie wyobcowania chłopca, który jeszcze przed opuszczeniem wspólnoty odczuwa swoją odmienność (rodzice chcieli „pogodzić go z ludźmi”, kształcąc go na księdza). Ostatni tekst, zatytułowany Dorastanie, to opis doświadczania gwałtownego uczucia do dziewczyny, ostatecznie oddzielającego bohatera od dzieciństwa, ojca i matki, co dobitnie podkreśla scena ze snu. Chłopak widzi przyzywających go do siebie rodziców, lecz nie może już do nich powrócić, w ostatnich słowach opowieści utożsamia się jednak z nimi: „I byłem równocześnie moim ojcem i moją matką. Byłem dorosły” (s. 135). Bohater ma świadomość zachodzącej w nim przemiany. Na swe wczesne doświadczenia patrzy już z perspektywy ex post. Mocno zaakcentowany zostaje tutaj motyw utraconego dzieciństwa, który powracać będzie w kolejnych utworach prozatorskich Nowaka, nie można go jednak sprowadzić do nostalgicznej świadomości upływu czasu czy pragnienia powrotu do stanu niewinności. Dzieciństwo jest bowiem - jak się wydaje - dla autora Wniebogtosów czymś więcej.

Zatem byłby ten tom zapisem doświadczenia inicjacyjnego - to jedna, bardzo istotna, możliwość. Sens „przebudzenia” wskazuje jednak także na przechodzenie z jednego stanu w inny. Określa moment, kiedy człowiek na krótko pozostaje na granicy między snem a jawą. Pamięta jeszcze to wszystko, co dopiero - we śnie - było mu wiadome, ale już w tej samej chwili zanurza się w rzeczywistość nie-senną. Unikam tu określenia „realną”, dla budzącego się człowieka są one wówczas równie prawdziwe. Ów moment przejścia to sytuacja, w której człowiek dysponuje w pewnym sensie dwojakimi narzędziami poznania. Taka interpretacja tytułu także akcentuje „przejście” - podobnie jak rytuał inicjacyjny. Nie ulega wątpliwości, że „przebudzenie” wskazuje bezpośrednio na stan pozostawania wcześniej we śnie. Sen zaś w twórczości Nowaka ma swoje szczególne znaczenie. Warto przy tej okazji pamiętać również o funkcji przypisywanej snom w dwudziestowiecznej myśli antropologicznej i psychologicznej, akcentującej ich poznawczy charakter. Specyficzny, symboliczny wymiar widzeń sennych podkreślali między innymi Erich Fromm czy

${ }^{8}$ Stosunek do niego przywodzi na myśl pojmowanie dzieciństwa w koncepcji Brunona Schulza i jego słowa o potrzebie dorastania do dzieciństwa.

9 E. Fromm, Zapomniany język, tłum. J. Marzęcki, Warszawa 1977, w wielu miejscach, między innymi s. 188 . 
Joseph Campbell ${ }^{10}$, uznając sen za wyraz znaczeń ukrytych w naszej podświadomości. Podobnie jak baśń i mit sny wyrażają - według tych koncepcji - treści wspólne całemu gatunkowi ludzkiemu niezależnie od czasu, miejsca i kultury, w których żyje człowiek. I co ważniejsze: sny zawierają posiadaną przez niego nieświadomą mądrość przekraczającą granice świadomości i poznania racjonalnego. Ten właśnie aspekt snu wydaje mi się najciekawszy w kontekście fabuł Nowakowej prozy.

Wreszcie jedno jeszcze znaczenie: „przebudzenie” może mieć konotacje negatywne, oznaczać gwałtowne wyrwanie z marzenia, urojenia, złudzeń. Może być chwilą konfrontowania, przysłowiowego „przejrzenia na oczy”, przykrego zderzenia z rzeczywistością. Wszystkie te odczytania można odnieść do treści debiutanckiego tomu prozy Nowaka.

A zatem z czego i do czego budzi się bohater Nowaka? Pierwszy fragment tomu nosi tytuł Wychodzenie ze snu, który z jednej strony jest synonimem przebudzenia, z drugiej jednak wskazuje na przenikanie jednej - sennej - rzeczywistości w drugą - nie-senną (wychodzi się z czegoś, wchodząc w coś innego). Świat senny jest dla chłopca w pełni realny i akceptowany, a spotykani w nim ludzie przyjaźni. Budzą ciekawość, dają poczucie bliskości. Jednak niemal natychmiast mieszają się ze „spotykanymi na drodze, w polu” (s. 7), których sam narrator-bohater nie od razu nazywa rzeczywistymi, później to określenie się pojawi, jakby świadomość oddzielenia sennych od nie-sennych wyłaniała się stopniowo. Więcej - stopniowo też rodzi się wiedza, jak postępować z jednymi i drugimi, „ale była to jeszcze wiedza półsenna ${ }^{11}$ [podkr. D.S.], dopiero próbowana w ustronnych zagajnikach, dopasowywana do tych, którzy opuścili mój sen, aby mnie wrzaskliwie obskoczyć i wciagnnąć w swój krąg" (s. 8). Mocno zmetaforyzowany język Nowaka wytwarza w świadomości czytelnika mglisty obraz wyłaniania się jednego świata z drugiego, wcześniejszego. Senny byt przepoczwarza się, miesza i rodzi wreszcie tę rzeczywistość nie-senną, całkowicie jednak w nią nie wnika. Jakaś część sennego bytu odchodzi, znika: „moi senni, nieruchomi ludzie, ustąpili całkowicie miejsca ludziom rzeczywistym. (...) Nie śmiałbym jednak zaprzeczyć, że nie tęskniłem do nich. Byli przecież dla mnie tak dobrzy, chociaż ich dobroć była jak las wyszywany na okiennych szybach przez mróz" (s. 10). To pierwszy etap utraty: zatarcie zdolności sennego widzenia i odejście bliskich, darzonych uczuciami „sennych ludzi”. Może to oczywiście być poetyckim opisem procesu zyski-

${ }^{10}$ J. Campbell, Potegga mitu, tłum. I. Kania, Kraków 1994, w wielu miejscach, między innymi s. 75.

${ }^{11}$ Warto zwrócić uwagę, że pośredniość, przechodzenie między sferami, przestrzeniami, stanami i tym podobne również będą powracać w twórczości Nowaka. Przykładem choćby tytuł jego późniejszego zbioru prozy: Pótbaśnie (I wydanie 1976 rok), o których ostatnio ciekawie pisała Iwona Wieczorek-Bartkowiak, Opowieści spod igty. Tekstura „Pótbaśni” Tadeusza Nowaka [w:] Nowy Nowak (Tadeusz), red. J. Olejniczak, R. Knapek, Katowice 2016, s. 145-158. 
wania przez dziecko samoświadomości ${ }^{12}$, niemniej dostrzegam także w owym „wychodzeniu ze snu” doświadczenie zanikania zdolności innego widzenia, które pozostanie obiektem tęsknoty i usilnych starań, by je w sobie przywracać, choć częściowo i momentalnie. Ów dar innego widzenia wiąże się ściśle z koncepcją poezji, twórczości rozumianej jako narzędzie poznania poza(bądź nie wyłącznie) rozumowego, opartego na wrażeniu, intuicji, doznaniu metafizycznym. Nieprecyzyjne te określenia wskazują wyraźnie trop Nowakowej myśli wiodący do poezji Bolesława Leśmiana ${ }^{13}$, a zatem i bergsonowskiego poznania intuicyjnego oraz wcześniejszych koncepcji romantycznych, wedle których poeta - jak dziecko, jak człowiek pierwotny - zachowuje wrażliwość na wszelkie przejawy transcendencji i udaje mu się poprzez własną twórczość dotykać tajemnic metafizycznych, podszewki świata. W Wychodzeniu ze snu ten sens nie zostaje jeszcze oczywiście wskazany wyraźnie i w pełni, to jedynie pierwszy krok ku takiemu postrzeganiu sytuacji człowieka, a pośrednio także i roli twórcy. Jest w tej opowieści również sens uniwersalny, odnoszący się do kondycji ludzkiej - świadomość jednostki wyłania się i oddziela z całościowego bytu, by wieść swą „realną” egzystencję ograniczoną poznawczo i niepełną. Motyw innego - pełniejszego - widzenia będzie powracał w prozie Nowaka wielokrotnie, zwłaszcza na przykład w Diabtach czy Wniebogtosach, gdzie zdolność tę posiada niewidomy brat głównego bohatera. Dar ów jest dla Pawełka czymś szczególnie upragnionym i utraconym, próbę odzyskania czy zastąpienia go stanowią właśnie opowieść, pieśń, tworzenie ${ }^{14}$.

Szczególną rolę w wizji świata dziecięcego bohatera Przebudzeń odgrywają zwierzęta. Początkowo postrzega on życie całej wsi jako zgodne z rytmem pór roku, z nadrzędnym, ustalonym porządkiem, którego zwierzęta są naturalną częścią. Metafory uwypuklają ścisłe związki między elementami tego uniwersum. Opis stwarza tu obraz gęsty, poetycki, niemal niemożliwy do rozdzielenia na poszczególne cząstki:

Zima do wsi nie przychodzi nigdy niespodzianie. Zanim zjedzie z pagórków zimy siwy koń, koty, jak na wiosnę bazie, przebierają się na zapiecku kocim w iskrzącą puszystość. A drobniutkie brzózki dla siwego konia zimy dosypują do żłobów strumieni coraz więcej owsianych listków. Dopiero wtedy Dunajec przytupuje na błę-

${ }^{12}$ Ten aspekt całych Przebudzeń akcentował Roch Sulima we wspomnianej już książce. Por. R. Sulima, Tadeusz Nowak, dz. cyt., s. 82-82.

13 Tadeusz Nowak wielokrotnie mówił o znaczeniu twórczości tego poety dla jego własnych koncepcji i przemyśleń, między innymi w szkicach Nieustanne poszukiwanie i Wejściowe drzwi [w:] Spowiedź wyobraźni (szkice i rozmowy), wybór i wstęp A. Jarzyna, Kraków 2014, s. 38-42 oraz s. 46-49. Związki światopoglądu, a nawet poetyki utworów Nowaka z twórczością Leśmiana warte są szczegółowego rozważenia. Badacze dzieła autora Obcoplemiennej ballady dostrzegali oczywiście istnienie tych zbieżności, były one zazwyczaj jednak tylko wzmiankowane.

${ }^{14}$ Więcej na ten temat piszę w szkicu „A gdy żebrakiem, gdy poeta będziesz...” - o „Wniebogtosach", kulturze ludowej i stowie [w:] Nowy Nowak (Tadeusz), dz. cyt., s. 167-187. 
kitnych wirach. (...) A z uszu siwego konia zimy żującego w sadzie sędzielaku listki, sypią się sikorki, a malinowe gile wylatują ze zgrzebnych rękawów pokutujących ostów (Zima, s. 12).

Nie jest to jednak wiejska idylla, ponieważ w świecie tym dokonane zostaje zabicie czarnego koziołka (tu pojawia się zaczątek istotnego w Diabtach epizodu związanego z ofiara) i trwa pamięć o rabacji. Jednak dominuje wrażenie całościowego porządku, w który wpisane jest ludzkie życie od narodzin po śmierć. Ten obraz świata - sensownego i opartego na trwałych zasadach będzie w późniejszej twórczości Nowaka ulegał znacznym zachwianiom, jeśli nie wręcz (choćby chwilowej) degradacji.

Jednak na razie jednym z jego fundamentów jest unia człowieka ze zwierzętami. Dziecięcy bohater odczuwa szczególną z nimi więź, porozumienie i bliskość. Przeczuwa w nich odrębny, fascynujący świat, pradawny i tajemniczy, opozycyjny względem człowieczej rzeczywistości. Wymyka się on poznaniu, jest „ledwie przeczuwany we śnie” (s. 17). Choć nie daje się pojąć całkowicie, stanowi niewątpliwie źródło wiedzy o sobie samym. Niejako w odbiciu natury rodzi się stopniowo wizerunek samego siebie - jakże znów mocno słychać tu echa leśmianowskich odbić i przenikań twarzy człowieka i natury: „Jedynie zwierzęta były dla mnie w tym czasie czymś w rodzaju małych czystych wód chodzących na czterech łapach, w których przeglądałem się od wewnątrz i na zewnątrz" (s. 18). Pierwszoosobowa narracja uwypukla niewypowiedziane wprost pragnienie bohatera, by dostęp do tajemnicy zwierzęcego świata, świata natury, uchwycić, zatrzymać, by ponawiać próby wnikania weń. W późniejszych utworach bohaterom będzie się czasem to przenikanie udawać, jak na przykład w Obcoplemiennej balladzie, kiedy to chłopiec pije kobyle mleko i dzięki temu ma wrażenie przejmowania części roślinnego świata do własnego wnętrza:

Zanim klacz straciła mleko, poczułem jak w moim wnętrzu rozjaśnia się trawa. Zwłaszcza szerokie listki zajęczej kapusty, podłużne listki stokłosy i dzikiej cykorii widziałem do samego dna najdrobniejszych żyłek. Niemalże całą istotą przeczuwałem w ich wnętrzu obecność kleistego soku. Bardzo mnie to ucieszyło. (...) Teraz dopiero w łące widziałem te praźródła, z których rodzi się mleko, krew, mięso i $\operatorname{sierść}^{15}$.

Niemniej opowieść snuta jest z perspektywy człowieka, który już przekroczył granice dorastania, wszedł głęboko w rzeczywisty, racjonalny świat, jedynie przez poetyckie słowo może uchylać drzwi do tamtej, utraconej rzeczywistości.

15 T. Nowak, Obcoplemienna ballada, Warszawa 1963, s. 9-10. 
Szczególne poczucie bliskości pomiędzy bohaterem a zwierzętami ma jeszcze inny aspekt. Przebywanie z nimi wyzwala, wydobywa na światło dzienne to, co głęboko skrywane. Ich obecność pozwala rozpoznawać wewnętrzną istotę własnego bytu, własnej świadomości. Inaczej niż wobec ludzi - przed zwierzęcymi przyjaciółmi chłopiec może odkrywać siebie: „I rzadko się zdarzało, abym w obecności moich rówieśników wychodził tak daleko $\mathrm{z}$ mego człowieczego wnętrza (...), w obecności zwierząt spowiadałem się z najtajniejszych zakamarków mojego dzieciństwa” (s. 19).

To odkrywanie siebie przed sobą wobec zwierząt w porządku kompozycyjnym całego tomu zapowiada następne etapy wtajemniczania, które oznaczają jednocześnie etapy ustalania się własnej tożsamości chłopca. Kolejne całostki/rozdziały to Ballada ztodziejaszka, Ballada pomylonego i Ballada Chrystusika. Spotkanie tych trzech postaci wyznacza proces formowania się samoświadomości bohatera. Najbardziej oczywisty jest kontekst adolescencyjny zarysowany już w pierwszej Balladzie - konieczność określenia swojego miejsca w gromadzie rówieśniczej i konflikt emocjonalny związany z przymusem dokonywania wyboru między lojalnością czy chęcią imponowania grupie, a rodzącymi się uczuciami do dziewczynki. Wtajemniczenie w miłość, erotyzm dokonuje się przy udziale złodziejaszka Jaśka. Jego litania - plan kradzieży konia, by jeździć do dziewczyny, nie tylko stanowi nawiązanie do typowych motywów folkloru, ale także ujawnia pewien stały porządek świata. Krótkie oznajmiające zdania mają moc potwierdzania prawidłowości wszystkiego, co jest:

Ukradnę konia. Koń jest mi potrzebny.

(...)

Ukradnę konia. Koń mnie zawiezie do dziewczyny.

Ukradnę konia. Dziewczyna jest mi potrzebna.

(...)

Ukradnę konia. Dziewczyna jest podobna do mojej matki.

Ukradnę konia. Matka też była kiedyś dziewczyną.

(...)

Ukradnę konia. Dziewczyny przecież nie mogę ukraść.

(...)

Ukradnę konia. Będę jeździł do dziewczyny (s. 30).

Złodziejaszek przez odśpiewanie przed chłopcem litanii utwierdza prosty i oczywisty ład, wpisuje zresztą weń i chłopca, zapowiadając, że musi on w przyszłości powtórzyć całą tę sekwencję zdarzeń. Na powtórzeniu opiera się zresztą także sama konstrukcja litanii, nie tylko przez anaforyczny początek każdego wersu, ale i przez zamkniętą - kolistą - kompozycję (fraza „Będę jeździł do dziewczyny” pojawi się na początku i na końcu). Ciekawsze jest jednak w tym tekście łączenie dwóch przeciwstawnych na pozór elementów: z jednej strony owo uporządkowanie, wiejski i kosmiczny ład, w którym wszystko jest 
takie, jakie ma być, a z drugiej postać złodziejaszka, łamiącego zasady społecznego współżycia przez zawłaszczanie cudzego dobytku. Jednak w prozie Nowaka tej sprzeczności nie ma. Motyw złodziejaszka będzie wracać wielokrotnie - w A jak królem, a jak katem będziesz... kradzież koguta można przecież postrzegać jako pierwszą inicjacyjną próbę bohatera, we Wniebogtosach Pawetek w analogicznej życiowej sytuacji kradnie kurę ${ }^{16}$. Złodziejaszek jest częścią tego kosmosu, jego los jedną z dróg, które można wybrać, a kradzież konia nie jawi się tu jako prawdziwe zło.

Motyw konia jako obiektu pragnień powtarza się w Balladzie pomylonego, w większym jeszcze stopniu symbolizuje tu pożądaną dorosłość i swobodę oraz więź między bohaterem a pomylonym, który nie tylko rozumie i poważnie traktuje twory wyobraźni chłopca, ale także ofiarowuje mu upragnionego konia. Ten, choć drewniany, unosi gdzieś w rozkołysany, odmieniony świat, równoległy do świata dorosłych ${ }^{17}$. Dziecko wtopione jest w dookolną rzeczywistość, w której równoprawnie współistnieje realne i wyobrażone, doświadcza zespolenia z naturą, zwierzętami i tymi z ludzi, którzy „patrzą inaczej”, ale mają swoje oczywiste miejsce w tym uniwersum. Stan ów wspominany z perspektywy dorosłego wydaje się upragniony i utracony.

W obu Balladach... mocno zaakcentowany zostaje (pojawiający się także wcześniej) motyw odbicia. Bohater w wodach stawu dostrzega swoją twarz podobną do twarzy złodziejaszka, a później i owego wymarzonego konia, i tę dziewczynkę, która go tak intryguje, tyle, że starszą o kilka lat, widzi przyszłość, tak rzeczywistą i namacalną jak teraźniejszość. Uchyla się niejako przed nim podszewka świata, by mógł widzieć więcej. Odbijanie jest w prozie Nowaka nierozłącznie związane z możliwością „innego” patrzenia, rozpoznania tego, co na co dzień niedostępne. W tym świecie można spoglądać przez pawie pióro tak, by odmieniać widziane: „Spojrzałem w sad. Zobaczyłem weselników. Ale nie byli to już ci sami weselnicy, którzy zjeżdżali do nas rano. (...) Przez nich przepływało światło" (s. 45-46). Można odbijać się w oczach psa i widzieć siebie inaczej. Upodobnienie się chłopca do pomylonego (jak wcześniej złączenie własnej twarzy z obliczem złodziejaszka) ${ }^{18}$, szczególna łączność z nim symbolizują kolejny wariant drogi, którą chłopiec może wybrać. Litania śpiewana przez pomylonego odkrywa sens tego losu, choć czyni to w niezwykle poetycki sposób:

${ }^{16}$ D. Siwor, dz. cyt., s. 175-176, 225.

17 Zastanawiające jest tu powtórzenie motywu drewnianego konia użytego w podobnym inicjacyjnym kontekście przez Brunona Schulza w tytułowym opowiadaniu Sklepów cynamonowych, w tym miejscu jednak nie mogę tego wątku rozwinąć.

${ }_{18}$ Związek między tymi postaciami a bohaterem jest wielokrotnie podkreślany, na przykład: „A mnie, leżącemu z otwartymi źrenicami, zdawało się, że obok mojego ciała śpi złodziej i pomylony" (s. 49). 
Chcę być pomylony. Pomyleni tkają sobą niewidzialne sukno. Chcę być pomylony. Pomyleni zaścielają suknem wszystkie ścieżki. Chcę być pomylony. Pomyleni najciszej prowadzą nas suknem. Chcę być pomylony. Pomyleni zostawiają nas na suknie ścieżek. Chcę być pomylony. Pomyleni wiodą suknem Boga (s. 47-48).

Proza Nowaka wymaga metod interpretowania właściwych poezji - tak jest intensywna i nasycona znaczeniami. W zacytowanym fragmencie uwidacznia się tęsknota do odmiennego stanu istnienia, odmiennej roli, do świadomości wykraczającej poza codzienne doświadczenie. Powtórzone wielokrotnie słowo „sukno” można rozumieć jako tkaninę świata splecioną misternie z wielu wątków, gdzie osnowa będąca fundamentem wzoru jest niewidoczna dla oczu. Rolą pomylonych jest nie tylko wytwarzanie sobą osnowy świata, ale i przewodzenie pozostałym, naprowadzanie na właściwy, choć ukryty sens. Pomyleni wprowadzają w świat Boga. W tym miejscu wyraźnie staje się widoczne, jaką trudność stanowi próba odczytywania Nowakowych tekstów, które bardziej nadają się do odczuwania niż rozumienia. Cóż bowiem znaczyć ma ów wers? Pomyleni byliby tu pośrednikami między człowiekiem a transcendencją? ${ }^{19}$ Kolejnym wcieleniem jurodiwych, świętych szaleńców? Bóg w twórczości autora Psalmów nie jest bynajmniej pojęciem jednoznacznym. Kolejne wersy zdają się potwierdzać tę pośredniczącą rolę pomylonych, ponieważ „ukrzyżowali siebie”, „zostawiają nas Bogu” i „odchodzą samotni”. Pomylony urywa litanię i tańczy, „podobny do wrzeciona”. Uosabia stwórczy ruch, niezbędny istnieniu, a w obrazach tych pobrzmiewa echo bergsonowsko-leśmianowskiego wichru życia. Nie zapominajmy przy tym, że pomylony jest tu także wariantem losu chłopca, świadomego swej odrębności, swego odmiennego widzenia; chłopca, który kiedyś będzie pisał ${ }^{20}$. Bohaterowie prozy Nowaka (z nielicznymi wyjątkami) to przecież w istocie kolejne wersje tego samego odczuwania świata, spójnego i wyrazistego.

Kompozycja Przebudzeń wyraźnie wskazuje, że Ballada ztodziejaszka i Ballada pomylonego stanowia pierwsze etapy wtajemniczenia. Kluczowym jego momentem (i środkowym tekstem tomu) jest Ballada Chrystusika. Spotkania ze złodziejaszkiem i pomylonym przygotowały chłopca na ten moment. Mówi o tym on sam, podkreślając szczególny stan, w którym się znajduje: „Byłem jasny, prześwietlony (...)" - światło jako atrybut wiedzy i poznania pojawia się tu nieprzypadkowo. Dalej mowa o „uchyleniu od wewnątrz” i przyjmowaniu, wkraczaniu rzeczywistości w bohatera (s. 50-51). Doświadczywszy świata widzianego oczyma pomylonego i złodziejaszka, bohater doszedł do miejsca,

${ }_{19}$ Kwestia świętości szalonych ma swą obszerną literaturę przedmiotu. Z pozycji nowszych warto wymienić książkę Cezarego Wodzińskiego, Ś $w$. Idiota, Gdańsk 2000.

${ }^{20}$ Wyjaśnianie związku pomiędzy Leśmianowską koncepcją poezji a obrazem-ideą pomylonego będącego ruchem stwarzającym świat wydaje mi się tu działaniem zbędnym. 
gdzie otwiera się na poznanie najistotniejsze. Doniosłość momentu podkreślają odświętne ubranie i wrażenia doznawane przez chłopca: „Szedłem tędy $\mathrm{z}$ wiosennej uciechy, nie wiedząc, że rozwiązana we mnie, jak wstążka u tba weselnego konia, świąteczna radość, była wyjściem naprzeciwko mojego trzeciego wtajemniczenia" (s. 51) Napotkany przez chłopca Chrystusik jest do niego podobny. I wiadomo, że chodzi tu o podobieństwo sięgające najgłębiej, istoty człowieczeństwa: „Popatrzył na mnie litościwie, uśmiechnął się, jakby się przejrzał w moim do siebie podobieństwie” (s. 52). Spotkanie odbywa się w przestrzeni jednocześnie realnej i świętej, trudno bowiem nie dostrzec znaczenia tak oczywistego gestu Chrystusika jak przemiana wody jeziora w wino i bryły ziemi w chleb ${ }^{21}$. Zresztą później bohater-narrator mówi wprost: „Najbliższe nam jezioro było jego jeziorem. Siedział nad nim i uciszał burzę, gdy z tamtego brzegu służący mu rybacy wyciągali sieci pełne ryb. (...) A mnie zasypiającemu zdawało się, że jestem dorosły, że jestem jednym z jego rybaków" (s. 57). Narastające stopniowo pragnienie i poczucie odnalezienia siebie samego w Chrystusiku wiąże się jednak z koniecznością odrzucenia poprzednich „wcieleń”. Chłopiec doświadcza rozdarcia:

Wtedy odezwał się we mnie złodziej. (...) Zatańczyło w mojej głowie słoneczko pomylonego. I miałem ochotę zmusić Chrystusika do przytupywań, pogwizdów i kołomyjkowego kręcenia się w kółko. Ale już wtedy wydawało mi się, że ograbię siebie, że siebie zmuszę do tańca. Bo już wtedy byłem przeniknięty, niemal przebity na wylot, jego pomieszanym z powszedniością apostolstwem. Zdawało mi się, że pomiędzy nami rozsupłała się osnowa, na której przędzie się nam wspólne, delikatne płótno. Uciszył się we mnie złodziej, uspokoił pomylony (s. 56).

Nie oznacza to jednak, że bohater pragnie boskiego losu. To w Chrystusiku objawia mu się to, co ludzkie. Zresztą litania Chrystusika powtarza słowa: „Chcę być człowiekiem”. Ballada ta ujawnia istotę człowieczeństwa zawierającą się w życiu samym, bliskim ziemi, zwierzętom, w zmysłowej przyjemności i w prawie do czczenia świętych. A także w „umieraniu na ziemi”. Smak życia zawiera się w jego intensywnej prawdziwości. Pragnienie Chrystusika zrealizować się może tylko przez współprzenikanie jego istnienia i losu chłopca. Toteż gdy po zakończeniu ballady Chrystusik staje się na powrót drewnianym klockiem $^{22}$, bohater, ustawiając figurkę pod drzewem, dokonuje tego utożsamienia: „wydawało mi się, że ustawiam siebie na to wielkie apostolstwo, obok którego będą przechodzili ludzie, dziękowali za nie zdrowaśką, ptasim piórkiem,

${ }^{21}$ Ciekawy - i bardzo dla Nowakowego widzenia świata charakterystyczny - jest motyw miodu; Chrystusik wychodzi z miodu lepki i zmuszony do wyciągania zeń włosów brody. Oczywiście miód nasuwa skojarzenia z rajem (topos raju jako krainy miodem i mlekiem płynącej).

${ }^{22}$ Wprowadzenie motywu baśniowej przemiany martwego przedmiotu w człowieka i na odwrót podkreśla właściwe dziecku postrzeganie świata. 
polnym kwiatkiem. I spodobało mi się takie pomyślenie siebie" (s. 59). Najistotniejszą treścią wtajemniczenia okazuje się odkrycie piękna i wartości człowieczeństwa, na tym bowiem ma polegać wspomniane tu apostolstwo.

Opisane tak szczegółowo trzy epizody-spotkania wyznaczają kolejne etapy przebudzeń bohatera. Za każdym razem zyskuje on świadomość siebie samego, widzenie siebie i swojej relacji ze światem. Zbliża się do rozstrzygnięć, wyborów, w których jakąś cząstkę siebie będzie musiał odrzucić, coś z widzenia świata utracić. Jak już wspomniałam na początku, stopniowo w krag doświadczeń bohatera wkracza historia, dotąd nieobecna. Żołnierze wychodzący ze stawu, choć nadal ukazywani w onirycznej aurze „innego widzenia”, wprowadzają myśl o złu, cierpieniu i śmierci innej niż ta, która w świecie kosmicznego ładu kończy ludzkie życie. Historia Mojżesza - żydowskiego kolegi ukrywanego przed prześladowcami i śmiercią z rąk żandarmów - nie pozwala już widzieć tylko piękna rozkołysanego sadu i uporządkowanego według odwiecznych rytmów świata. Tytułowe Przebudzenia są opowieścią o opuszczaniu własnego miejsca, o utracie. Chłopiec wyjeżdżający do miasta ma świadomość, że bliski jest przekroczenia granicy, za którą nie można już do pewnego stanu odczuwania powrócić. Dobitnie wyrażają to słowa: „Do tej pory jeszcze nic nie utraciłem. Jechałem nadal taki, jaki byłem uprzednio jakby poza mną jechało na oddzielnych wozach całe moje dzieciństwo" (s. 109-110). Przeczuwa zmianę, jej nieodwracalność: „Wydawało mi się, że dorastam do kogoś mi przeznaczonego, ale nigdy nie przeczuwanego i zupełnie bezbronnego" (s. 116). Później, w Dorastaniu, bohater powie: „Ta nowa, objawiona mi nagle postać, w którą miałem wstąpić, była dla mnie zbyt tajemnicza, abym mógł bez oporu wejść w nią i nią rozporządzać" (s. 132). Bohater stoi na granicy dorosłości, w miejscu, w którym nie ma już odwrotu. Przyjmuje nieuchronność tego procesu, wychodzi dorosłości naprzeciw, a jednak towarzyszy temu dojmujące poczucie utraty. Wracamy zatem tym samym do wskazanych na początku tego szkicu możliwych znaczeń tytułowego słowa „przebudzenia” - rozumianego jako budzenie się świadomości, zyskiwanie wiedzy o świecie, jako synonim doświadczenia inicjacyjnego. Jednak wskazane powyżej interpretacyjne tropy kierują ku odczytywaniu owych aktów przebudzeń także jako narastającego, dojmującego poczucia utraty. Obejmuje ono owe nieświadome, intuicyjne poznanie dane dziecku, przekraczające granice postrzegania racjonalnego. Dorastanie oznacza utratę owego „innego widzenia”, które wywodzi się z mitu, baśni, snu i łączy świat w spójną całość (albo Pełnię), pozwala doznawać niemal utożsamiającej więzi ze zwierzętami, sadem, rzeką. Odczucia te nie ograniczają się jednak do tęsknoty za doznaniem jedności, wykraczają poza nostalgię za minionym, poza mitologizację utraconego dzieciństwa. W prozie Nowaka chodzi - jak sądzę - o coś więcej. „Przebudzenia” jako powtarzająca się sytuacja egzystencjalna to uświadamianie sobie braku. Zwielokrotnianego w każdym akcie przejścia ze snu do jawy, w każdej decyzji o odrzuceniu możliwego wariantu losu, w każdym dokonywanym wyborze. Ów stan „bu- 
dzenia" tożsamego z doznawaniem braku będzie się w kolejnych utworach powtarzać, ale i rozszerzać na inne jeszcze aspekty świadomości i dookolnej rzeczywistości. Obejmie także doświadczenie utraty poczucia obecności Boga, miłości do świata, porządku i sensu istnienia. Albo jak - pisze Stanisław Balbus - doświadczenie „zaniku wartości metafizycznych”23. Różne są wymiary owej straty, dotyczą zarówno jednostkowego losu, jak i świata otaczającego bohatera, narratora, autora i czytelnika. Ból związany z jej doznawaniem bądź tylko zagrożeniem nią będzie powracać zarówno w poezji, jak i w prozie autora Psalmów, a jego twórczość będzie w jakiejś mierze ciągłą walką, by ów brak zażegnać, powstrzymać stratę. W ostatniej wydanej za życia powieści, we Wniebogtosach, okaże się ostatecznie, że jedynym może sposobem jest utrwalanie w opowieści. Powtarzanie w słowie, w pamięci, powtarzalność bowiem jest przeciwko śmierci, a co za tym idzie, także przeciw zanikowi i utracie. Bohater Wniebogtosów, podejmując spisywanie historii własnej rodziny, w tym utrwalaniu w słowie widzi możliwość docierania do traconej Całości ${ }^{24}$.

Pierwszy tom prozy Tadeusza Nowaka nie tylko zawiera motywy, wątki i znaczenia istotne dla całej późniejszej twórczości pisarza, dla widzenia świata i jego sensu, ale i wskazuje na szczególną ranę 25 , która odciska się piętnem na ludzkim życiu. Pisanie staje się konieczną i stale podejmowaną próbą jej zasklepiania. Od Przebudzeń po Wniebogtosy toczy się koło Nowakowej prozy.

\section{Bibliografia}

Balbus S., Poezja w czasie marnym [w:] T. Nowak, Modty jutrzenne - modty wieczorne, Kraków 1992.

Bolecki W., Poetycki model prozy $w$ dwudziestoleciu międzywojennym. Witkacy Gombrowicz-Schulz, Kraków 1996.

Campbell J., Potęga mitu, tłum. I. Kania, Kraków 1994.

Fromm E., Zapomniany jezyk, tłum. J. Marzęcki, Warszawa 1977.

${ }^{23}$ S. Balbus, Poezja w czasie marnym [w:] T. Nowak, Modty jutrzenne - modty wieczorne, Kraków 1992, s. 153. Stanisław Balbus pisze o dramacie utraty przede wszystkim w odniesieniu do I Pacierza azjatyckiego w kontekście cyklu Pacierzy azjatyckich i Pacierzy diabelskich, a pojęcia braku i utraty odnosi do określonych aspektów światopoglądu Nowaka na tym etapie twórczości. Chciałabym tu proponować bardziej uogólnione rozumienie doznania utraty.

${ }^{24}$ Szerzej na ten temat pisałam we wspomnianym już szkicu: „A gdy żebrakiem, gdy poeta będziesz...” - o „Wniebogtosach", kulturze ludowej i stowie, dz. cyt., s. 167-187.

${ }^{25}$ Motyw rany pojawia się niejednokrotnie w poezji Nowaka. Zwracali na to uwagę między innymi Stanisław Balbus we wspomnianym już szkicu Poezja $w$ czasie marnym oraz Roch Sulima, który pisał: „Rzeczywistość boli jak nigdy nie zabliźniająca się rana, którą się przede wszystkim czuje, o której się wreszcie myśli”. R. Sulima, O źródtach poetyki Tadeusza Nowaka [w:] tegoż, Folklor a literatura, Warszawa 1976, s. 293. 
Nowak T., Jasetkowe niebiosa, Warszawa 1957.

Nowak T., Obcoplemienna ballada, Warszawa 1963.

Nowak T., Przebudzenia, Kraków 1962.

Nowak T., Spowiedź wyobraźni (szkice i rozmowy), wybór i wstęp A. Jarzyna, Kraków 2014.

Nowy Nowak (Tadeusz), red. J. Olejniczak, R. Knapek, Katowice 2016.

„Podróż do miejsca urodzenia”, scenariusz i reżyseria A. Czarnecka i D. Pawelec, TVP S.A. oddział w Krakowie dla Pr. 2, 2001.

Siwor D., W kręgu mitu, magii i rytuatu. O prozie Tadeusza Nowaka, Kraków 2002.

Sulima R., O źródtach poetyki Tadeusza Nowaka [w:] tegoż, Folklor a literatura, Warszawa 1976.

Sulima R., Tadeusz Nowak, Warszawa 1986.

Wodziński C., Św. Idiota, Gdańsk 2000. 